\title{
The Role of New Media in Communicating to Beneficiaries of Ngos Working in Kajiado County, Kenya
}

\author{
Patriciah Muia \\ Daystar University, Nairobi, Kenya \\ Clayton Peel \\ Namibia University of Science and Technology (NUST), Windhoek, Namibia
}

\begin{abstract}
Organizations serving rural communities in Kenya have found use for media as a tool of replacement for personal interface in the daily communication with the beneficiaries of their programmes in deprived areas. The interactions between two non-governmental organizations (NGOs) and rural beneficiaries in Isinya, Kajiado County, provide case studies of how NGOs modernize their outreach via new media and how beneficiaries respond to the change. The research was not only concerned with the presence of information technology (IT) and online facilities in remote and deprived locations. It also evaluated responses to the replacement of person-to-person contact with technologies, such as social media, the Internet, Compact Disc-Read Only Memory (CD-ROMs), and Digital Versatile Disc (DVDs). Conducted in four focus groups, the research evaluated the uptake of new media technologies by beneficiaries following the transition, asked whether beneficiaries engaged with the materials being communicated, and assessed whether this confluence of technology and culture had eased the flow of communication, or unsettled it. Evidence of discomfort among the older (over 50-year-old) beneficiaries stemmed from fear of failure to master the technologies and a desire for a continuation of regular interpersonal interaction with the NGO field officers (whose field trips were scaled back in preference of computer-mediated communication). However, younger (under 40-year-old) beneficiaries were less insistent on regular interpersonal visits and were appreciative of the use of technology, and of the building of Maarifa Centres to give the beneficiaries free access to internet, DVDs, and hard drive-based information materials. Another demographic, beneficiaries aged between 40 and 50 years old, said they were not comfortable with the change and wanted the interpersonal interaction to continue, but were open to a longer-term transition once the beneficiaries were all conversant with the uses of the new technologies. The study recommends a better managed transition that accommodated the beneficiaries' fears, misgivings, and cultural preference for verbal, face-to-face consultation.
\end{abstract}

Keywords: social media, new media, NGO s, traditional media, beneficiaries, social networking sites

\section{Introduction}

New media are utilized by a range of organizations, including non-governmental organizations (NGOs)—for communicating with their publics and stakeholders (Shama, 2010). The technology and access

Patriciah Muia, MA, Lecturer in Corporate Communication, Department of Communication, Daystar University.

Clayton Peel, Ph.D., Senior Lecturer in Communication, Department of Communication, Namibia University of Science and Technology (NUST). 
has helped NGOs to innovate as they reach out to stakeholders by Internet and mobile cellular channels. NGOs working in Kenya are in that quest to modernize communication tools, even when working with deprived communities of varying literacy and information access levels. This paper makes an assessment of new media adoption by the beneficiaries of two international NGOs working in Kajiado County, Kenya (Arid Lands Information Network [ALIN] and Compassion International) and their initial technology-assisted outreach. The novelty has made the responses of beneficiary communities critically important, especially as the innovations tend to move from the face-to-face oral communication that (Ndimele, 2005) is favoured by African cultures. Has this confluence of technology and culture eased the flow of communication, or unsettled it?

The beneficiaries with whom these NGOs are working have had some level of uptake of new media technologies. Age, literacy, and access to technology were the main factors that contributed to the variation in uptake between the two NGOs' constituencies. This concurs with Ruggiero (2000) who argued that the use of new media requires an active audience.

ALIN wants to be "more directly involved in engaging the end users of its information in order to ensure that the information delivered through its Kenya, Uganda, and Tanzania-based Maarifa Centres help end users to improve their livelihoods", says a blog called the Isinya Citizen Voices which the organization has generated with and for its benificiaries in Isinya, Kajiado (ALIN, 2013). Maarifa is a Swahili word meaning "knowledge", and the technology-equipped Maarifa Centres, so named because they are intended to be the centres of knowledge aquisition and transfer, are used by the rural communities to access free internet, e-government services, multimedia content, online market information, publications and library, advisory services, and information and communication technology (ICT) training opportunities.

With the Maarifa Centres as hubs, but not the sole conduits of interaction with the rural communities, the NGO seeks to create awareness of health, lifestyle, and poverty alleviation options, and to disseminate this information to the communities living there. Knowledge transfer of the sort that these NGOs specialise in is particularly apt for a place, like Kajiado, which is characterised by drought, poverty, illiteracy, poor infrastructure, poor sanitation, female genital mutilation (FGM), and other adverse factors that attract humanitarian NGO interest (Kabuthu, Muchoki, \& Nyaga, 2005-2010). This paper investigates which new media tools were used by the two NGOs in communicating with the people they served, an interest informed by pre-research evidence of some NGO-client engagement through social media.

The selected NGOs were present through their corporate pages on various online social networks, such as Facebook, Twitter, and the interactive forums of their institutional websites, and so the research wanted to find out the extent to which the new media platforms were successful in reaching their beneficiaries and how beneficiaries responded to the communication infrastructure. The significance of the use of these tools to communicate with beneficiaries in an area of low literacy levels such as Kajiado merited added attention.

\section{Rationale}

The adoption of new media in the public relations and development communication practices of aid organisations and their beneficiary publics in under-developed contexts brings a new uses and effects dynamic to communication scholarship. While there is evidence that the use of new media has offered outlets for NGOs to increase their fundraising, advocacy reach, and recruitment of volunteers (Boyer, 2012; Eyrich, Padman, \& Sweester, 2008), there is rather less scholarly material to suggest that the implications of NGO-beneficiary interactions using new media have been studied. This paper will be informative in highlighting the experiences 
of ALIN and Compassion International. An analytical approach and its findings will be of interest to NGOs with operations in Kenya, especially the public relations practitioners in the NGO sector. The findings of the study could give insights to the NGOs on what new media tools they could use to connect with their beneficiaries, and thereby, enhance their outreach to those communities. There is also the possibility that this study will enhance knowledge in the field of corporate communication research, such that its findings test the boundaries of what may be achieved by organizations which are bold enough to optimise use of the new media platforms. This may provoke a review of research strategies and yield further research gaps to be pursued.

\section{Theoretical Framework}

The social construction theory as well as the uses and gratifications theory explain the pattern of adoption of social media by the community under study. Much as the two centers were attempting to introduce the use of social media to the community, it is important to understand that the success of such endeavours relies on social acceptance by the recipients of the usability of both the information and its channels, which is what informs social constructionism. Social construction theory holds that the recipients of knowledge and its enabling technologies have to appropriate data and channel according to their perceptions, and test the applications thereof according to their needs, before they adopt the tools and content.

\section{Social Constructionism Theory}

The proponents of this theory are Berger and Luckmann (1991) who maintained that change is brought about by human activity. They note that while reality is always socially defined, it is individuals and groups of individuals who define it. The theory further accepts that there is an objective reality and is concerned with how knowledge is constructed and understood. In social constructionism, people can be agents of change. Social constructionism originated as an attempt to come to terms with the nature of reality. Social constructionists view knowledge as constructed as opposed to created. Constructionists view knowledge and truth as created, not discovered by the mind (Schwandt, 2003). This therefore explains the importance of paying attention to the reception and utilization of the new media channels by the beneficiary community under study.

\section{The Uses and Gratification Theory}

Community adoption of and interaction with social media is propelled by the uses the people make of the technology, and the gratification they get from it. People will choose the communication channel based on its usefulness for their needs and purposes. In other words, the gratification they get from it. In this study, how the beneficiaries respond to the use of the tools, and the reasons behind it, with the needs and aspirations of both end users and the NGOs taken into account, helps to understand the concepts of uses and gratification in the dissemination and reception of information via pre-selected channels. The decisions taken to use the channels, and the outcomes measured by both the NGOs and the beneficiaries, suggest there may be divergent gratifications according to different expectations. Hence, there is the constructionist argument of the other theory. Media users are aware of what they want from the media tool they choose to use, and will evaluate it depending on availability and satisfaction. This is the evaluation we are looking for in the interface between NGOs, their social media tools, and the expectations, uses and gratifications of the beneficiary communities in Kajiado.

The NGOs, as the information disseminators, make choices, too: They tend to adopt one communication channel and not the other, depending on factors which might include transmission speed, cost, reliability, 
availability, and convenience. As senders, they have a use and gratification set of motives, just as the beneficiaries do. They want the most effective medium for their message and they want the best results. The beneficiaries, on the other hand, may choose to use certain media depending on its availability and their exposure to the particular media. The end result of all this is gratification by the NGOs and the beneficiaries, since every choice of a new media tool leads to some form of gratification. We have designed the diagram below based on our perception of NGOs' choices of social platforms and decisions of why they use them.

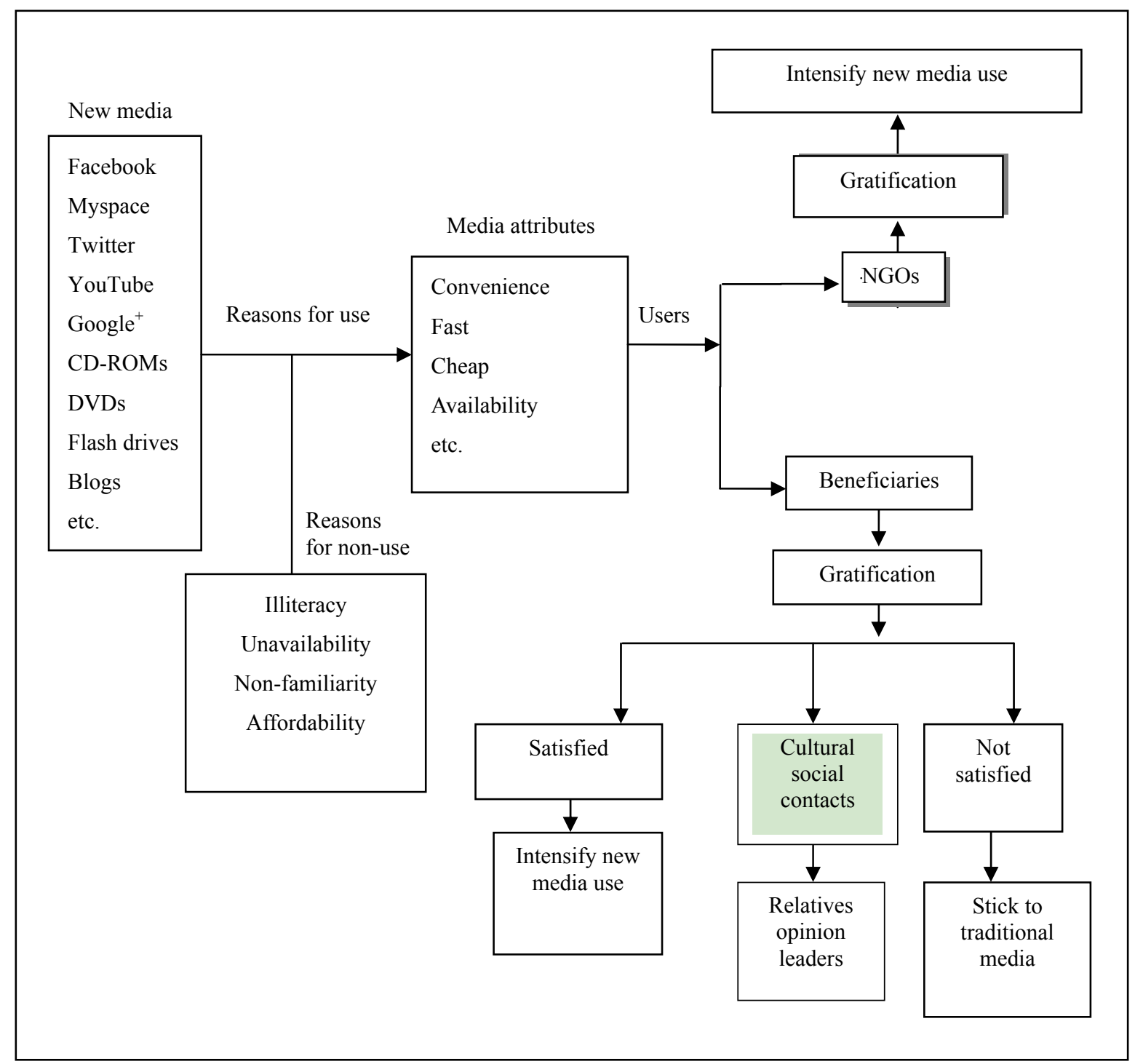

Figure 1. A reflection of uses and gratification and new media use by NGOs and beneficiaries.

\section{Discussion}

Figure 1 shows how the new media platforms available to the NGOs can provide a channel for interaction with their constituencies in a way that potentially produces user gratification at both ends: the NGO disseminators and the beneficiary constituencies as receivers. The NGOs mount the media platforms with the aim of communicating messages and are gratified by the ease with which the new platforms enable them to complete that communication. The beneficiaries, potentially, might also experience gratification through the 
knowledge they perceive and the feedback they are able to give to the NGOs in the interaction. Thus, the diagram illustrates the different forms of new media which include Facebook, Twitter, YouTube, Google ${ }^{+}$, Compact Disc-Read Only Memory (CD-ROMs), Digital Versatile Disc (DVDs), Flash Drivers, and Blogs, and how they have attributes which might attract NGOs to use these new media tools in communicating and connecting with the people they serve. Some of the possible reasons for adopting these new media tools might be of convenience, speed, cost effectiveness, and availability. The end result of the whole process is gratification on the part of the NGOs which intesifies their use of the tools. The beneficiaries' gratification might explain which media is likely to be adopted (or rejected) based on the attributes associated with the new media tools. The NGOs' choices were influenced by the conveniences of the new media's attributes by the NGO employees, the knowledge, level of education, and exposure to the new technologies by the beneficiaries of the NGOs' programmes.

\section{Methodology}

This was a qualitative study that employed the use of focus group discussions (FGDs) and in-depth interviews. Four FGDs were used for the beneficiaries, while the interviews targeted staff of the two NGOs.

As regards the members of the beneficiary communities, their participation in the FGDs came by way of screening for those who had interacted with the NGOs for longer periods of time. Using a list from the centre directors of members who had benefitted from the organizations' programmes, we selected participants on the basis of years of experience. FGDs were included in this study to find out their level of awareness (as beneficiaries) of the new media used by the two NGOs in communicating to them, and if they were interacting with the materials being communicated to them. Two FGDs were convened for each organization: there were 19 participants in the FGDs aligned to ALIN and its work (nine in one group and 10 in the other), while Compassion International beneficiaries were canvassed in two equal groups of 10 (thus, 20 participants in all). The total number of participants in the four FGDs was 39.

Purposive sampling was used to select NGO staff involved with the Maarifa Centres and the communication strategies driving the outreaches in Kajiado. The staff members selected were considered best placed, in terms of knowledge of the outreaches in Kajiado, to have the information relevant to the objectives of the study.

Although we were aware of the dynamics of inter-gender focus groups, and strived to achieve gender balance and age variation while encouraging those traditionally constrained from expressing their views in public fora, such as women to be comfortable in responding to the questions from the research team, the overriding criteria for inclusion was length of association with either NGO.

\section{Data Collection Method}

Data was collected using FGDs and in-depth interviews. FGDs constitute a qualitative research in which groups of people are asked about their perceptions, opinions, beliefs, and attitudes towards a product or service. In this case, questions were asked in interactive group settings where participants were free to talk with other group members. Each FGD lasted one and a half hours. The discussions were conducted in the Swahili language to cater for those with non-formal education (NFE). FGD participants turned up in good numbers and were willing to participate. The answers obtained were transcribed into the English language. The FGDs were selected from among the beneficiaries of the NGOs' programmes. 
Table 1

Composition of the Focus Groups

\begin{tabular}{|c|c|c|c|c|}
\hline Participants & Age & Gender & Occupation & Education \\
\hline $\begin{array}{l}\text { ALIN: FGD One } \\
\text { Participant } 1 \\
\text { Participant } 2 \\
\text { Participant } 3 \\
\text { Participant } 4 \\
\text { Participant } 5 \\
\text { Participant } 6 \\
\text { Participant } 7 \\
\text { Participant } 8 \\
\text { Participant } 9\end{array}$ & $\begin{array}{l}24 \text { years old } \\
22 \text { years old } \\
40 \text { s years old } \\
26 \text { years old } \\
28 \text { years old } \\
33 \text { years old } \\
26 \text { years old } \\
42 \text { years old } \\
40 \text { years old }\end{array}$ & $\begin{array}{l}\text { Male } \\
\text { Male } \\
\text { Female } \\
\text { Female } \\
\text { Female } \\
\text { Female } \\
\text { Male } \\
\text { Male } \\
\text { Male }\end{array}$ & $\begin{array}{l}\text { Computer student } \\
\text { Computer student } \\
\text { Farmer } \\
\text { Business lady/Computer student } \\
\text { Teacher/Computer student } \\
\text { Farmer } \\
\text { Extension officer/Computer student } \\
\text { Farmer } \\
\text { Livestock farmer }\end{array}$ & $\begin{array}{l}\text { Form Four } \\
\text { Form Four } \\
\text { NFE } \\
\text { Form Four } \\
\text { Bachelor of Education (B.Ed.) } \\
\text { Standard Eight } \\
\text { Bachelor of Science (BSc) Agriculture } \\
\text { Standard Eight } \\
\text { Standard Six }\end{array}$ \\
\hline $\begin{array}{l}\text { ALIN: FGD Two } \\
\text { Participant } 1 \\
\text { Participant } 2 \\
\text { Participant } 3 \\
\text { Participant } 4 \\
\text { Participant } 5 \\
\text { Participant } 6 \\
\text { Participant } 7 \\
\text { Participant } 8 \\
\text { Participant } 9 \\
\text { Participant } 10 \\
\end{array}$ & $\begin{array}{l}22 \text { years old } \\
26 \text { years old } \\
26 \text { years old } \\
22 \text { years old } \\
23 \text { years old } \\
20 \text { years old } \\
21 \text { years old } \\
24 \text { years old } \\
20 \text { years old } \\
23 \text { years old }\end{array}$ & $\begin{array}{l}\text { Female } \\
\text { Female } \\
\text { Male } \\
\text { Male } \\
\text { Female } \\
\text { Male } \\
\text { Male } \\
\text { Male } \\
\text { Female } \\
\text { Female }\end{array}$ & $\begin{array}{l}\text { Computer student } \\
\text { Housewife/Computer student } \\
\text { Agricultural extension officer } \\
\text { Computer student } \\
\text { Computer student } \\
\text { Computer student } \\
\text { University student } \\
\text { High school teacher } \\
\text { Computer student } \\
\text { College student }\end{array}$ & $\begin{array}{l}\text { Form Four } \\
\text { Standard Eight Diploma } \\
\text { Form Four } \\
\text { Form Four } \\
\text { Form Four } \\
\text { Degree student } \\
\text { BEd } \\
\text { Form Four } \\
\text { Degree student }\end{array}$ \\
\hline $\begin{array}{l}\text { Compassion: FGD One } \\
\text { Participant } 1 \\
\text { Participant } 2 \\
\text { Participant } 3 \\
\text { Participant } 4 \\
\text { Participant } 5 \\
\text { Participant } 6 \\
\text { Participant } 7 \\
\text { Participant } 8 \\
\text { Participant } 9 \\
\text { Participant } 10 \\
\end{array}$ & $\begin{array}{l}60 \text { s years old } \\
50 \text { s years old } \\
33 \text { years old } \\
38 \text { years old } \\
40 \text { s years old } \\
50 \text { s years old } \\
52 \text { years old } \\
50 \text { s years old } \\
60 \text { s years old } \\
70 \text { s years old } \\
\end{array}$ & $\begin{array}{l}\text { Male } \\
\text { Male } \\
\text { Female } \\
\text { Female } \\
\text { Female } \\
\text { Male } \\
\text { Male } \\
\text { Female } \\
\text { Female } \\
\text { Male }\end{array}$ & $\begin{array}{l}\text { Care giver } \\
\text { Care giver } \\
\text { Business lady } \\
\text { Care giver } \\
\text { Care giver } \\
\text { Livestock farmer } \\
\text { Care giver } \\
\text { Care giver } \\
\text { Care giver } \\
\text { Care giver }\end{array}$ & $\begin{array}{l}\text { NFE } \\
\text { NFE } \\
\text { Form Four } \\
\text { Standard Seven } \\
\text { NFE } \\
\text { NFE } \\
\text { NFE } \\
\text { Standard Four } \\
\text { NFE } \\
\text { NFE }\end{array}$ \\
\hline $\begin{array}{l}\text { Compassion: FGD Two } \\
\text { Participant } 1 \\
\text { Participant } 2 \\
\text { Participant } 3 \\
\text { Participant } 4 \\
\text { Participant } 5 \\
\text { Participant } 6 \\
\text { Participant } 7 \\
\text { Participant } 8 \\
\text { Participant } 9 \\
\text { Participant } 10 \\
\end{array}$ & $\begin{array}{l}40 \text { s years old } \\
50 \text { s years old } \\
36 \text { years old } \\
42 \text { years old } \\
70 \text { s years old } \\
50 \text { s years old } \\
60 \text { s years old } \\
39 \text { years old } \\
34 \text { years old } \\
32 \text { years old }\end{array}$ & $\begin{array}{l}\text { Male } \\
\text { Male } \\
\text { Female } \\
\text { Male } \\
\text { Male } \\
\text { Female } \\
\text { Female } \\
\text { Male } \\
\text { Female } \\
\text { Male } \\
\end{array}$ & $\begin{array}{l}\text { Farmer } \\
\text { Farmer } \\
\text { Care giver } \\
\text { Livestock farmer } \\
\text { Livestock farmer } \\
\text { Housewife } \\
\text { Housewife } \\
\text { Livestock farmer } \\
\text { Business lady } \\
\text { Businessman } \\
\end{array}$ & $\begin{array}{l}\text { NFE } \\
\text { NFE } \\
\text { Standard Three } \\
\text { Standard Eight } \\
\text { NFE } \\
\text { NFE } \\
\text { NFE } \\
\text { Form Four } \\
\text { Form Four } \\
\text { Form Four } \\
\end{array}$ \\
\hline
\end{tabular}

The FGDs are aligned to ALIN and its work (nine in one group and 10 in the other). The first group had three participants aged 40 and above, while the remaining six were aged 33 and below. This group had five males and four females (see Table 1). The second FGD of ALIN beneficiaries had 10 participants (five females and five males) aged 20-26. Compassion International had an FGD of 10 participants (two aged 33 and 38, while the ages of the remaining eight ranged from 48 to the $70 \mathrm{~s}$ ). The second Compassion International group had four participants aged 34-40, and the remaining six were between ages of 42 years and the 70 s. Most of the the constituents of the Compassion International outreach had NFE. ALIN, on the other hand, served a lot of young people, so the FGDs of its constituents comprised young participants who had varying levels of formal education. 
The results of both the FGDs and the in-depth interviews were presented thematically in narrative form, and then, the key findings of the research were summarized.

\section{Description of Key Interview Respondents and Participants}

Six members of staff took part in the in-depth interviews. Two were from ALIN and four from Compassion International. We decided to interview four employees from the Compassion International Isinya Centre who we considered were key informants: a social worker who dealt directly with the community, a health worker familiar with the outreach's achievements in health issues, one child survival worker who dealt with child protection, and the Centre Director, who oversaw the running of the whole organization. On the other hand, ALIN had two employees at the time the study was conducted: a field officer and a community knowledge facilitator, who was also the trainer.

At Compassion International, the centre director was a male of 36 years old, with a bachelor's degree in Counselling Psychology. He had worked with the organization for nine years. The health worker was a female aged 23 who had worked with the organization for two years and had a bachelor's degree in Community Development and Peace Studies. The social worker was a female aged 25 who had been with the organization for three years. She had a diploma in Community Development. The child survival worker was a female aged 35 and had been with the organization for three years. She had a diploma in Early Childhood Development.

\section{New Media Usage in Communicating With Beneficiaries}

We sought to find out if the employees of the two organizations used new media to communicate with the beneficiaries of their programmes. The employees from ALIN conceded to using these platforms in communicating with the beneficiaries, though they admitted that not all beneficiaries engaged with the materials they sent them. This they said was as a result of non-familiarity with the tools by some of the beneficiaries. However, the interviewees revealed that they had Maarifa Centres (information hubs) where beneficiaries of the programmes were encouraged to register for free computer classes and be able to access the information they required. The two employees acknowledged that some of the beneficiaries were very active in engaging with these materials and this made their communication easier.

From Compassion International, all of the four admitted that they did use new media to reach the beneficiaries though they said that uptake was quite low. The reason for this was that a good number of their beneficiaries, especially the parents of the children who benefit from their programmes, had little or no formal education.

\section{New Media Most Frequently Used}

We sought to establish which new media tools were frequently used by the employees to reach their beneficiaries and why. Employees from ALIN used Short Messaging Service (SMS) most frequently for direct communication with the beneficiaries. The reason for the frequent use of SMS was that the majority of the beneficiaries had mobile phones, so NGO workers were confident that messages would reach the beneficiaries in real time. The field officer who has a bachelor's degree in Information Science, explained that she engaged with some of the beneficiaries via Facebook and Twitter, but at a minimal rate. She was aware that some of the beneficiaries could not access these platforms as they had no internet, for they live in rural areas where internet cannot be accessed easily. The field officer's observation is backed by findings from the FGD that a majority of the FGD participants engaged with the NGO mostly through SMS. This is backed by evidence from one of the 
FGD participants from Compassion International who had this to say concerning the use of SMS as a mode of communicating to the organization.

Mtoto anapogonjeka, mimi huwapigia simu au kuandika SMS kwa watu wa Compassion ili waniambie ile hospitali nitampleka kwani wao ndio hulipa pesa za hospitali

When the child falls sick, I call or send SMS to the people from Compassion who advise me which hospital to take him to as the organization caters for their hospital expenses.

In another FGD from ALIN, all the 10 participants said that ALIN had interacted with them on their phones, especially via SMS when they wanted to inform them of the arrival of magazines, or to remind them about graduation dates.

The employees from Compassion International also said that SMS was the most commonly used new media tool for interaction with beneficiaries familiar with new communication technology. They said most beneficiaries had access to mobile phones and those who could read received SMSs with important information concerning the NGO-assisted programmes, which they in turn passed on to their neighbours who could not read.

Compassion International also used DVDs to transmit information. These were used by the social worker, the child survival worker, and the health worker to record and transmit success stories of the beneficiaries to their donors as well as the stakeholders. They said that this worked very well for the beneficiaries as they could well relate with the organization and say how much they had benefitted from the programmes.

The social worker and the centre director said that they also used Facebook as a few of the beneficiaries used this outlet, too. This finding implies that even though the employees were familiar with most of the new media tools, they did not engage the beneficiaries through all of them. The reason for this was that most of the beneficiaries did not use these social sites due to lack of exposure or/and illiteracy.

\section{New Media Tools Used Least Frequently}

The interviewees were asked to identify the new media tool they used least frequently to reach the beneficiaries. Those from ALIN said that the tool they used the least was You Tube and MySpace, while those from Compassion International said the least used were podcasts for the reason that none of the beneficiaries were familiar with them.

\section{Messages Communicated on the Social Sites}

The researcher sought to find out messages the employees of the two NGOs communicated with the beneficiaries on social networking platforms. The response from the ALIN employees was that they send beneficiaries SMSs and emails to inform them of the arrival of the Baobab and Joto Africa magazines, reminded them of seminars, graduations of computer students, cancellation of computer classes, and visitations by donors. They also sent the magazines as attachments to those with e-mail accounts. The magazines contain information on how to conserve energy, preserve the environment and how to make energy-saving cookers. The organization also provided DVDs to the beneficiaries concerning ways of sustainable agriculture, sustainable energy use and climate change. The beneficiaries can watch such DVDs at home (for those with electricity at home), so they do not have to travel to the centre to get this information. This finding reveals that the ALIN employees were active in using the new media technologies to reach their beneficiaries who were in turn receptive as they got back though the same channels. 
The employees from Compassion International explained that they used new media for different purposes. The health worker said that she sent messages to the beneficiaries to tell them about the arrival of vaccines for children, when there was food to be distributed to the children, family planning, and proper hygiene. The social worker sent messages to the beneficiaries to tell them about the dangers of FGM, female literacy, and projects that could earn them some money. The child survival worker said that she sent messages to the care-givers to sensitize them on child protection, advocacy issues, gender equality, and the dangers of FGM, while the centre director communicated about seminars to be held or meetings with donors who support the vulnerable children programme among others. This finding shows that the employees engaged with the beneficiaries using the available means and involved them in the programmes of the organization.

\section{Whether New Media Attracted Successful Interaction With Beneficiaries}

The researcher also sought to find out if the use of new media really attracted any interaction with the beneficiaries. The response from the community knowledge facilitator at ALIN was that there was interaction mostly through SMS while the other tools were slowly taking shape on her part. She attributed this to her daily interaction with a wider community which included some illiterate beneficiaries, some of whom could not even read the SMS. She revealed that for some, she resorted to calling them (if they had mobile phones) or even sent messages by word-of-mouth for the information to reach them. DVDs were also handy in this respect, as the beneficiaries could watch with their families and get clarification when needed. This trend was most common with the aged beneficiaries. The field officer revealed that she preferred using Facebook and Twitter to reach the youth, but engaged the older beneficiaries via SMS and cell phone calls. This finding reveals that from the perspective of the disseminating organisations, communication by means of new media attracted interaction with the beneficiaries, especially those who were able to engage with information from the new media platforms.

For Compassion International, all the four employees explained that there was interaction especially from those few beneficiaries who were able to engage with the social platforms. They said that most of the beneficiaries were not familiar with most new media tools and this limited their use of such platforms to reach beneficiaries. Traditional media like word-of-mouth, phone calls, opinion leaders, and seminars took prominence in achieving this as most of the beneficiaries still relied on them for communication. This implies that the use of traditional media was still vital in this organization if the employees had to achieve their objective of reaching each of their beneficiaries.

\section{Combining New Media Tools With Traditional Media}

To establish if traditional media were still being used by the two NGOs, we asked the employees whether new media tools were combined with traditional media to communicate with the beneficiaries. Phone calls were notably combined with SMS in most cases to reach the beneficiaries at ALIN. Other tools cited were the use of seminars, word-of-mouth, posters, and opinion leaders. Combining these tools with the new media tools was seen by the employees to lead to effective communication. They explained that this ensured all beneficiaries were reached in one way or another, and this helped them attain the objectives of the programmes. Both employees said that word-of-mouth was mostly used for people who could not read and write, and did not have mobile phones. Posters were mostly used during seminars and were hung on the walls for those who could read.

For Compassion International, the four employees said that they also combined modern and traditional tools as a means of communication with the beneficiaries. They explained that the traditional tools were used 
more than the new media tools. This was attributed to low literacy levels among most of the beneficiaries, hence unavailability, and non-familiarity with new media tools among majority of the beneficiaries. The traditional media mostly used were posters, phone calls, word-of-mouth, seminars, and opinion leaders. Opinion leaders were most useful when it came to advocacy issues or issues touching on social lives, health, and child protection. The employees said that the beneficiaries had a lot of trust in the school head teachers, the area chiefs, as well as church leaders, whom the NGOs found reliable as traditional routes of mobilization and of disseminating information. The implication of this finding is that the organizations should not be in haste to abandon the traditional forms of communication because they are still important in the beneficiary communities.

\section{Whether Use of New Media Reduced Communication Costs}

The employees were also asked if they thought the use of new media could significantly lead to reduction of costs of communication. To this, the ALIN employees responded that if new media were fully adopted by all beneficiaries, then communication costs could go down significantly. They said that some of the traditional media used were costly and cumbersome to produce, like the posters. The ALIN employees also stated that these traditional media tools were not as fast as the new media tools

However, the employees from Compassion International explained that the issue of cost reduction was not very high on their agenda at the moment as they still heavily relied on the traditional media to reach their beneficiaries, many of whom have little or no formal education. This was because most of their beneficiaries were aged care-givers or the old who were very poor. For this reason, those who engaged with the new media were significantly fewer. This had caused the organization to rely heavily on the traditional media to disseminate information to the beneficiaries. However, the few who could engage with materials from the social media sites made the task easier for the employees as the cost was reduced, according to respondents. This observation reaffirms what was also stated by employees of the other NGO that the use of new media to reach beneficiaries could reduce communication costs within an organization if the channels were fully adopted.

It was clear in some instances that the less literate informants relied on cultural social networks for information, even though the informants themselves did not have access to the information technology channels.

\section{Noticeable Changes in Using New Media Tools}

There was also a question on whether there were noticeable changes (in terms of communication and increase of beneficiaries) in the NGOs' communication with the beneficiaries resulting from the introduction of the new media platforms. For the employees of ALIN, the changes had been significant, especially among the youth and literate adults. Both these groups gave feedback on the information sent to the social platforms. As a result of this interaction, the ALIN employees recorded an increase in the numbers enrolling for computer classes from 20 per class to 28 , evidence that the beneficiaries were keen on the new technology and increasingly likely to be able to interact with the materials from the NGO that were sent to them. The ALIN employees reported that they also received feedback from the farmers who were given DVDs and magazines about improved farming methods. According to the NGO workers, the beneficiaries had reported that, as a result of the new media materials, they had felt better equipped to deal with the challenges of drought, which Kajiado faces from time to time. 
The positive impressions from the ALIN workers were not evident among the Compassion International employees, however, who said that there were no significant changes as a result of the social networking platforms since only four from the FGDs were able to engage with the materials. For the few who were able to engage with the new media tools, a change was seen in that they were eager to learn using more channels and they were able to give feedback to the organization via the same channels. This finding shows that the use of new media platforms could generate more two-way communication between the organization and the beneficiaries.

\section{Posting Personal Information on Social Sites}

Apart from using the social platforms to communicate with beneficiaries, the interviewees were asked if they engaged with these channels to post personal information. The field officer from ALIN said that she was on Google ${ }^{+}$, Facebook, Twitter, and WhatsApp. She said that she used these cites to communicate with friends and read international news. The community knowledge officer was on Twitter, Facebook, LinkedIn, and WhatsApp. She said that she used these sites to bond with friends but LinkedIn was for both bonding with colleagues and looking for job opportunities.

All the four employees from Compassion International said that they heavily used the social platforms to post personal information. The centre director said that he was on Facebook, Twitter, YouTube, and Yahoo Chat. He engaged with these platforms to read and post success stories of beneficiaries, look for donors, attract volunteers and communicate with other stakeholders. The health worker was on Facebook, Twitter, LinkedIn, YouTube, and Google ${ }^{+}$. She said that she used these sites to communicate with friends and read success stories of beneficiaries. The child survival worker and the social workers said that they used Facebook, Twitter, and YouTube. They used these sites to interact with friends and read or post success stories. This finding confirms the personal affinity of these officers to the social media platforms and implies that their use of these outlets is both for personal communication and creates avenues for reaching wider audiences. These could therefore provide good opportunities for reaching out to communities who are scattered in a wider area. It would be very easy to reach them wherever they are instead of calling for meetings or making phone calls which are a bit costly.

\section{Research Findings}

The findings of this study have been presented and discussed on the basis of the four research questions.

\section{Research Question 1: Are the Selected NGOs Using New Media Tools to Communicate and Connect With the People They Serve?}

The findings to this question were that the NGOs used new media tools to communicate with the beneficiaries. However, ALIN used the social platforms to reach its beneficiaries more than Compassion International. This was attributed to the presence of the Maarifa Centres (Information hubs) set up by ALIN for the communities, where beneficiaries were able to take classes in computer technology. This allowed some of the beneficiaries to use the social networking platforms and other internet services.

The low usage rate at Compassion International was attributed to low literacy levels and non-familiarity with the new media by many of the beneficiaries as one participant reported,

Kama mimi sijui kusoma na kuandika nitawezaje kufungua hiyo kitu unaita computer? Wacha nisomeshe watoto wangu ndio wawe wakitumia hiyo 
If I personally cannot read and write, how do you ever expect me to know how to operate that thing you are calling a computer? Let me educate my children so that they may use it instead.

Studies show that when NGOs do not maximize the use of social media, they present a one-way communication, failing to engage the stakeholders interactively (Waters et al., 2009; Briones et al., 2011). Engaging with beneficiaries through social media would therefore create a two-way mode of communication.

The NGOs confirmed that they found the use of new media to communicate with beneficiaries convenient, fast, and cheap. These findings are comparable to studies by Bach and Stark (2001), Kahn and Kellner (2004), Gurstein (2000), and Schuler (1996). The use of new media by these NGOs concurs with Alikilic and Atabek (2012), Wright and Hinson (2008), and Curtis et al. (2010) who asserted that social networking sites have been widely used by NGOs. Therefore, the use of new media tools to communicate with beneficiaries could also afford NGOs, even in a rural set up in Kajiado, low costs, and convenience.

\section{Research Question 2: Is the Use of New Media by Selected NGOs Attracting Interaction With Beneficiaries in Kajiado County?}

The use of new media by ALIN attracted interaction between the organization and the beneficiaries. This was because most of the beneficiaries were able to engage, using new media, with the materials sent to them by the organization, so there was feedback between the organization and its beneficiaries. One beneficiary of this organization's work responded,

Mimi hutumiwa e-mail ikiwa na attachment ya magazine ile imetoka, halafu nafungua na kusoma hiyo magazine na kujifunza mambo ya ukulima nakutengeneza hii jiko mpya kwa hivyo sihitaji kuja kwa centre kuuliza

I get e-mails with an attachment of the latest magazine, Baobab or Joto Africa. This way, I am able to read the magazine from wherever I am and learn more about new farming methods and making energy-saving stoves. For this reason, I do not need to come to the Maarifa Centre to get such information.

This concurs with Ruggerio (2000), who argued that the use of new media requires an actively engaged audience with the interest to download material, as is the case with this beneficiary of ALIN. There was less evidence of this at Compassion International, however, as the interaction between the NGO and its beneficiaries through new media tools was minimal.

Although both NGOs engage their beneficiaries through social media, ALIN has engaged more, thus being able to address a lot of social issues via the social networking programmes. Age, literacy, and access to technology were the main factors that contributed to the variation in uptake between the two NGOs' constituencies.

\section{Research Question 3: Are Beneficiaries Aware of the NGOs' Use of New Media to Communicate With Them?}

Beneficiaries' awareness of new media use varied among the beneficiaries of the two NGOs. Most beneficiaries from ALIN were aware of the channels used by the organization to reach them. They presented knowledge of the channels and were also able to interact with them. This finding agrees with the uses and gratifications theory which gives a relationship between the users of a technology and the technology itself (Guo, Cheung, \& Tan, 2008). Interaction with the social media platforms was driven by the five tenets of the uses and gratifications theory: that audiences are active in their media choice, audiences' choices are goal-driven, media choices fill multiple needs, audiences are aware of their needs when choosing their media of choice, and the needs are specifically related to a specific media (McLeod \& Becker, 1981). Users of new 
media are usually goal-oriented in selecting media by choosing sources to fulfil their needs, assuming alternatives exist.

From Compassion International, only very few (four out 20 respondents), presented knowledge of the new media tools used by the NGO. This was attributed to illiteracy, non-familiarity with the new media, and unavailability of the technology.

\section{Research Question 4: Are Beneficiaries Engaging With the Materials Being Communicated by the NGOs?}

Beneficiaries engaged with the materials being communicated by the NGOs to varying degrees. There was quite high uptake of new media at ALIN by 15 out of the 19 members of the FGDs, with only four not engaging with the new media tools. The four who did not engage did not have education up to Form Four level. The rest were fully active in interacting with the material communicated to them by the NGO. Studies reviewed in literature show that when beneficiaries engage with online materials sent to them, it helps an organization to plan for programmes (Esrock \& Leitchy, 1998; Perry, Taylor, \& Doerfel, 2003; Springton, 2001). For this reason, ALIN has been able to plan for its programmes as the beneficiaries engage with the social networking programmes.

However, beneficiaries at Compassion International presented a very low rate of interaction with the online materials, with only four out of 20 being able to interact with the online information sent to them. This made it difficult (as reported by the NGO employees) for the organization to plan outreach activities through new media channels. These findings are comparable with those of Horton (2009) and Bach and Bryant (2007), who argued that failure to have proper use of the social sites by NGOs would make it difficult for them to conduct their outreach activities as the traditional forms of media would be quite expensive.

The high uptake of social media by ALIN as well as its beneficiaries explains the gratification of people choosing a specific media as outlined by Kaye and Johnson (2002), Ancu and Cozma (2009), Leung, (2009), and Parke, Kee, and Valenzuela (2009) who argued that the theory has been used to explain computer mediated communication and social media. The beneficiaries of ALIN demonstrated sufficient use and interaction with the new media for different purposes. This finding concurs with Ruggiero (2000) and Lin and Jeffres (1998) concerning the uses and gratifications theory that new media, especially internet-based media, requires a deliberately active audience, and navigating the web requires users to be specifically goal-directed. When both the organization and the beneficiaries engage through these social sites, they find gratification in the use and both are likely to increase the level of usage and engagement with the new media platforms

Further, the low uptake of the new media by the Compassion International beneficiaries was an indication of how illiteracy and lack of access can obstruct the majority of the beneficiaries from finding gratification in new media channels of communication (as revealed during the FGDs), with the result that they remain mostly engaged through traditional media. From the perspective of NGOs and their operations, this has implications for cost and convenience, as the traditional modes of interaction are rather costly and time consuming

ALIN had relatively young beneficiaries who were also educated, thus high levels of engagement and interaction with information on the social networking sites characterized this NGO's communication outreach in Kajiado.

In contrast, only six participants in the Compassion International FGDs had some education, accounting in large measure for the low levels of engagement with new media in this organization's Kajiado constituency. 
In terms of the new media outlet most frequently used, the results of the in-depth interviews and FGDs indicate that SMS messages were the most frequently used by both employees and beneficiaries from the two NGOs

\section{Discussion of the Study Findings}

In discussing the findings of this study, the author would like to employ the social construction theory as well as the uses and gratifications theory which will be used to explain the pattern of adoption of social media by the community under study. Much as the two centers were attempting to introduce the use of social media to the community, it is important to understand that ICT comes with social determination which is informed by the social constructivism. Social construction theory purpots that peope have to appreciate something before they adopt it.

The findings were that ALIN used new media platforms more than Compassion International to communicate with their beneficiaries and that the uptake of social platforms was highest among the youth demographics and those who had some formal education. This was an indication that ongoing efforts by the NGOs to influence new media communication practices in their beneficiary constituencies may need to focus on the youth within those constituencies.

The beneficiary communities demonstrated varying degrees of awareness of the channels, showing that there is a disconnect between the intent and practical measures by NGOs to take full advantage of new media, and the levels of engagement by a significant portion of the beneficiaries in Kajiado.

However, there should also be an awareness that a proportion of the beneficiaries still rely on the traditional channels of communication like person-to-person consultations, seminars, word-of-mouth, posters, and so on. Therefore, while accepting the merits of new media use and encouraging it where circumstances allow, NGOs should not be hasty in abandoning these traditional media as they are still useful, even if costly options.

Social Constructionism and why their adoption of the social platforms was divided. There was expressed desire of the community members to learn. Nontheless, there was a generational divide in the adoption process which is likely to cause hinderances.

\section{Conclusion}

The interface between new technologies and the level of service that benefiting communities receive from development agencies in less developed areas of emerging economies cannot be evaluated without due consideration of the cultural expressions that may be altered or even impeded in the transitions that come with technological adoption. It was certainly the case that ALIN, with its outreach to rural communities made less labour-intensive by the introduction of the knowledge hubs (Maarifas), allowed a cost-effective and user-centred access to the services it offered. However, these IT-centred channels marginalised the less literate, in a context already marginalized by economic, educational, and geographic limitations. Implementation of new technologies in less literate settings of the emerging world should therefore consider the social fragmention in the receiving context, and implement the new media channels alongside a retention of the conventional ones, for example face-to-face communal gatherings, as the social system would require. This way, a technologically-determined advancement in communication with rural communities would be welcome progress, but its pace of implementation would also be socially conditioned by literacy, generational, and wider cultural needs of social segments within those communities. 


\section{References}

Alikilic, O., \& Atabek, U. (2012). Social media and adoption among Turkish public relations professionals: A survey of practitioners. Public Relations Review, 38(1), 56-63.

ALIN (Arid Land Information Network). (2013). Maarifa (Knowledge) Centres: Improving Communities' access to knowledge and skills through Maarifa centres. Retrieved from https://www.alin.or.ke/ Accessed 22/05/2018

Ancu, M., \& Cozma, R. (2009). MySpace politics: Uses and gratifications of befriending candidates. Journal of Broadcasting \& Electronic Media, 53(4), 567-583.

Bach, J., \& Stark, D. (2001, October). Innovative ambiguiies: NGOs use of interactive technology in Eastern Europe. Retrieved from http://www.coi.columbia.edu/pdf/bach_stark_ia.pdf

Berger, P. L., \& Luckmann, T. (1991). The social constructionof reality. London: Penguin Books.

Boyer, K. (2012). Social media and non-profits:Increasing fundraisingand volunteerismfor the kahlo cultural centre california polytechnic. San Luis Obispo: California Polytechnic State University.

Briones, R. L., Kuch, B., Liu, B. F., \& Jin, Y. (2011). Keeping up with the digital age: How the American Red Cross uses social media to build relationships. Public Relations Review, 37(1), 37-43.

Curtis, L., Edwards, C., Fraser, K. L., Gudelsky, S., Holmquist, J., Thormton, K., \& Sweetser, K. D. (2010). Adoption of social media for public Relations by non-profit organizations. Public Relatons Review, 36, 90-92.

Esrock, S. L., \& Leichty, G. B. (1998). Corporate social responsibility and corporate Web sites: Self-presentation or agenda setting? Public Relations Review, 24(3), 305-319.

Eyrich, N., Padman, M. L., \& Sweester, K. D. (2008). Public relations practitioners' use of social media tools and technology. Public Relations Review, 34(4), 412-414.

Government of Kenya. (2005). Kajiado Distrct Strategic Plan 2005-2010: Implementation of the national population policy for sustainable development-national agency for population and development. Nairobi: Government Printers.

Guo, Z., Cheung, F. B., \& Tan, K. (2008). Motivations for using CMC and Non-CMC media in learning contexts: A uses and gratifications approach. Proceedings from The 29th International Conference on Information Systems (ICIS'08). Paris.

Gurstein, M. (2000). Community informatics: Enabling communities with information and communication technologies. Hershey, PA: Idea Group Publishing.

Horton, J. L. (2009). Are corporations using Facebook? Retrieved November 20, 2011, from http://docs.google.com/ viewer

Kahn, R. (2004). New media activism: From the "Battle of Seatle" to blogging. Retrieved from http://nms.sagepub. com

Kaye, B., \& Johnson, T. (2002). Online and in the know: Uses and gratifications of the web for political information. Journal of Broadcasting \& Electronic Media, 46(1), 54.

Leung, L. (2009). User-generated content on the internet: An examination of gratifications, civic engagement and psychological empowerment. New Media \& Society, 11(8), 1327-1347.

Lin, C., \& Jeffres, R. (1998). Predicting adoption of multimedia cable service. Journalism Quarterly, 75, 251-275.

McLeod, J., \& Becker, L. B. (1981). The uses and gratifications approach. In D. Nimmo \& K. Senders (Eds.), Handbook of Political Communication (pp. 137-162). Thousand Oaks: Sage Publications.

Ndimele, O. (2005). Globalization and the study of languages in Africa. Port Harcourt, Nigeria: Grand Orbit Communications/Emhai Press.

Park, N., Kee, K., \& Valenzuela, S. (2009). Being immersed in social networking environment: Facebook groups, uses and gratifications, and social outcomes. CyberPsychology \& Behavior, 12(6), 729-733.

Perry, D. C., Taylor, M., \& Doerfel, M. (2003). Internet based communication in crisis management. Management Communication Quarterly, 17(2), 206-233.

Ruggerio, T. E. (2000). Uses and gratifications theory in the 21st century. Mass Communications and Society, 3(1), 3-37.

Schuler, D. (1996). New community networks: Wired for change. New York, NY: Addison Wesley.

Schwandt, T. A. (2003). Three epistemological stances for qualitative inquiry: Interpretativism, hermeneutics and social constructionism. In N. Denzin, \& Y. Lincoln (Eds), The landscape of qualitative research: Theories and issues (pp. 292-331). Thousand Oaks, CA: Sage.

Shama, S. K. (2010). Reviewing NGOs media startegies: Possibilities for NGO media collaboration. International NGO Journal, $5(4), 84-87$.

Springston, J. K. (2001). Public relations and new media technologies: The impact of the Internet. In R. L. Heath (Ed.), Handbook of Public Relations (pp. 603-614). Thousand Oaks, CA: Sage Publications. 
Waters, R. D., Burnett, E., Lamm, A., \& Lucas, J. (2009). Engaging stakeholders through social networking: How non-profit organizations are using facebook. Public relations Review, 35(2), 102-106.

Wright, D. K., \& Hinson, M. D. (2008). How blogs and social media are changing public relations and the way it is practiced. Public Relations Journal, 2(2), 1-21.

\section{Appendix 1: Focus group guide}

1. What are the most common programmes offered by this organization?

2. Does everyone have a phone?

3. Could you tell me what messages the organization sends to you on the phone?

4. Does the organization send text messages to you?

5. When the does the organization send text messages to you?

6. Does the organization call you on the phone?

7. What do they communicate to you?

8. Through which other ways does organization communicate to you?

9. Are you able to access the internet?

10. For what purposes do you use the internet?

11. What messages are put on the internet?

12. Which social networking sites are you conversant with?

13. Do you respond to the organization through any of these social networking sites?

14. Could you please tell me some other ways through which the organization communicates to you?

15. Which communication channel do you prefer the organization to use most to communicate to you?

16. Why do you prefer this channel most?

\section{Appendix 2: In-depth interview schedule}

1. Do you use new media tools in communicating with the beneficiaries of your programmes? If so which ones?

2. Which new media tools do you frequently use to reach your beneficiaries? Why?

3. Which new media tools do you use least frequently to communicate with the beneficiaries of your programmes? Why?

4. What messages do you commonly communicate with the beneficiaries on these social sites?

5. Do these new media tools attract what you would call successful interaction with the beneficiaries?

6. Do you combine the new media tools with old media tools like, posters, bill boards etc in communicating with your beneficiaries? If yes, which ones? Why?

7. Do you think new media can significantly lead to reduction of cost of communication?

8. Are there any noticeable changes in your communication with beneficiaries before and after you started using these social platforms?

9. Do you post any personal information on any of the social networking platforms? If you do, which sites? What kind of information do you post? 